\title{
Influence of Curing Temperatures on the Properties of Fibrous Concrete
}

\author{
Noha M. Soliman, Alaa A. Bashandy \\ Civil Engineering Department, Faculty of Engineering, Menoufia University, Egypt
}

\begin{abstract}
Curing takes place immediately after concrete placing and finishing. Curing conditions affect on the concrete properties. One of those conditions is curing temperature. This research aims to study the effect of curing temperatures on the main mechanical properties of fibrous concrete compared to that of conventional concrete. Two types of fibers were used, polypropylene and steel fibers. The effect of temperature of curing $\left(25^{\circ} \mathrm{C}, 50^{\circ} \mathrm{C}\right.$ and $\left.75^{\circ} \mathrm{C}\right)$ was considered. The study is performed depended on the results obtained from compressive test, indirect tensile and flexural test at 3, 7 and 28 days. The test results showed that, the increasing ratio of the tensile strength and the flexural strength was better than the increasing ratio of the compressive strength with using the fibers in concrete compared to the control concrete. The curing temperature affected on the compressive strength more than the effecting of the tensile strength and the flexural strength. The better used curing temperature is about $50^{\circ} \mathrm{C}$.

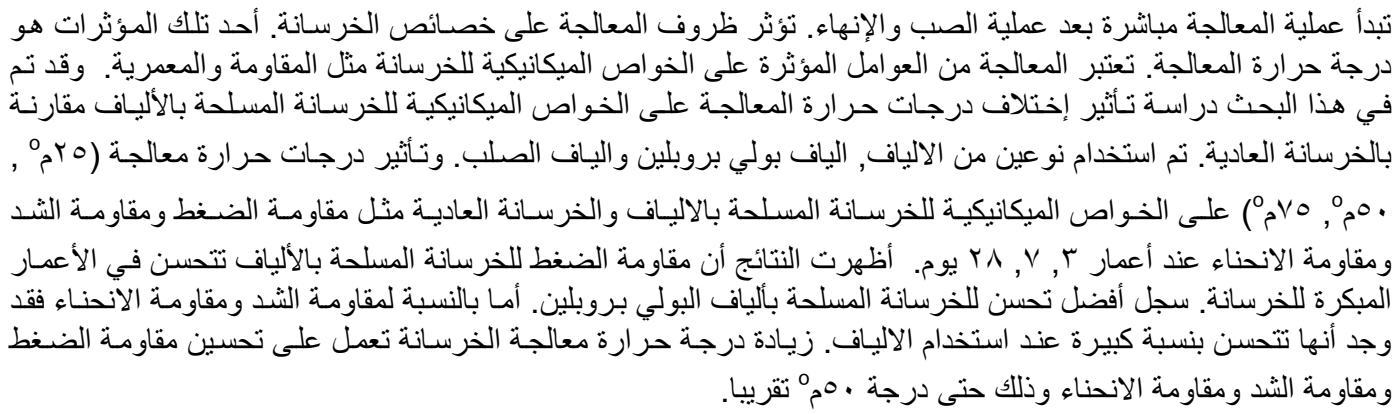

Keywords: Concrete; Fiber; Reinforcement; Curing; Temperature

\section{1- Introuduction}

The curing conditions effect on the main mechanical properties of hardened concrete such as strength development and durability of concrete. Curing takes place immediately after concrete placing and finishing. The cured concrete has an adequate amount of moisture for continued hydration, development of strength, volume stability, and resistance to freezing, thawing, abrasion and scaling resistance. The required curing time is dependent on the several factors such as: type of cementitious materials used, mixture proportions, specified strength, size and shape of concrete member, ambient weather conditions and future exposure conditions $[1,2]$.

Curing in either cold or hot weather requires additional attention. One of the important aspects of curing is temperature that the concrete can't be too cold or too hot. As fresh concrete gets cooler, the hydration reaction slows down. The temperature of the concrete is what's important here, not necessarily the air temperature. Below about $10^{\circ} \mathrm{C}$, hydration slows down a lot; below about $5^{\circ} \mathrm{C}$, it virtually stops. The temperature of fresh concrete shall be above $10^{\circ} \mathrm{C}$. The curing period for cold weather concrete is longer than the standard period due to reduced rate of strength gain. Compressive strength of concrete cured and maintained at $10^{\circ} \mathrm{C}$ is expected to gain strength half as quickly as concrete cured at $23^{\circ} \mathrm{C}$ [3]. In hot weather, curing and protection are critical due to rapid moisture loss from fresh concrete. The curing actually starts before concrete is placed by wetting substrate surfaces with water. Sunscreens, windscreens, fogging, and evaporation retardants can be used for hot weather concrete placements. Since concrete strength gain in hot weather is faster, curing period may be reduced [4].

High early age strength is achieved in concrete by accelerated curing techniques. These techniques are especially useful in the prefabrication industry, wherein high early age strength enables the removal of the formwork within 24 hours, thereby reducing the cycle time, resulting in cost-saving benefits [5].

At heightened temperatures, the hydration process moves more rapidly and the formation of the Calcium Silicate Hydrate (CSH) crystals is more rapid. The formation of the gel and collared is more rapid and the rate of diffusion of the gel is also higher. However, the reaction being more rapid leaves lesser time for the hydration products to arrange suitably, hence the later age strength or the final compressive strength attained is lower in comparison to normally

Engineering Research Journal, Vol. 37, No. 2, April 2014, PP: 2£ v-20 . 
cured concrete. This has been termed as the crossover effect [6-9].

One of those techniques is using heated water to cure the concrete. The effect of curing temperature on concretes was studied and test results indicated that the curing temperature of $50^{\circ} \mathrm{C}$ is better than that of $25^{\circ} \mathrm{C}$ and $75^{\circ} \mathrm{C}$ for the curing process of concrete mixes [10]. The optimum temperature has been found to be between 65 and $70{ }^{\circ} \mathrm{C}$, beyond which the losses in later age strength have been found to be considerably higher [11].

This research is performed to study the effect using different temperature of curing water on the behavior of fibrous concretes compared to conventional concrete. The compressive, splitting tensile and flexural strength during the different concrete ages was recorded.

\section{Research Significance}

This research is performed to study the effect of curing temperature (temperature of curing water) on the main mechanical properties of concrete mixes reinforced with fibers. The main variables in this research are curing temperature $\left(25^{\circ} \mathrm{C}, 50^{\circ} \mathrm{C}\right.$ and $75^{\circ} \mathrm{C}$ ), type of concrete (plain concrete and fibrous concrete) and fibers type (steel fibers and polypropylene fibers). The results are obtained in terms of compressive strength, indirect tensile strength and flexural strength. Comparisons are performed for each concrete type and curing temperature.

\section{Experimental Program}

The experimental program conducted in this study was performed in the laboratory of testing of building materials at the Faculty of Engineering, Menoufia University, Egypt. Cubes 100x 100 x100 $\mathrm{mm}$, cylinders $100 \times 200 \mathrm{~mm}$, beams 100x100x400 $\mathrm{mm}$ and cylinders $150 \times 300 \mathrm{~mm}$, were cast and tested to determine the compressive strength, indirect tensile strength and flexural of concrete mixes respectively. The effect of curing temperatures $\left(25^{\circ} \mathrm{C}, 50^{\circ} \mathrm{C}\right.$ and $\left.75^{\circ} \mathrm{C}\right)$ on the main mechanical characteristics of fibrous concrete compared to that of conventional concrete. Two types of fibers were used, polypropylene and steel fibers. The study is performed depended on the results obtained from compressive, indirect tensile and flexural strength at 3, 7 and 28 days.

\subsection{Materials}

\subsubsection{Fine aggregate}

The fine aggregate (F.A.) used in the experimental program was the natural siliceous sand. Its characteristics satisfy the Egyptian Standards (E.S.S 1109/2008) [12]. It was clean and nearly free from impurities with a specific gravity of 2.6 and a fineness modulus of 2.7.

\subsubsection{Coarse aggregates}

The coarse aggregate (C.A.) used was crushed dolomite, which satisfies the E.S.S 1109/2008 and ASTM C33 Specifications [12, 13] with a specific gravity of 2.7 and a fineness modulus of 6.64 . The shape of these particles was irregular and angular. The delivered crushed dolomite was size 1, which was available with a nominal maximum size of 9.5 $\mathrm{mm}$.

\subsubsection{Cement}

The cement used was the ordinary Portland cement (CEM 42.5 N), from the Suez cement factory. Its chemical and physical characteristics satisfy the Egyptian Standard Specification (E.S.S. 4756-1/ 2009) [14].

\subsubsection{Water}

The clean drinking fresh water free from impurities was used for mixing and curing the tested specimens according to the Egyptian code of practice.

\subsubsection{Fibers Used}

Two types of fibers are used namely steel fibers and polypropylene fibers.

i) Polypropylene Fiber PP 300-e3 was used. It was available in the Egyptian markets. It was used in concrete mixes to produce fibrous concrete and to improve the concrete characteristics. The percentage of fiber was chosen as $980 \mathrm{gm} . / \mathrm{m}^{3}(0.28 \%$ by cement weight). The mechanical properties of Polypropylene Fibers (300-e $\mathrm{e}^{3}$ ) are given in Table (1).

ii) Steel fibers (Harex) were used. It was available in the Egyptian markets. It was used in concrete mixes to produce fibrous concrete and to improve the concrete characteristics. The percentage of this type of fiber was also taken as $980 \mathrm{gm} . / \mathrm{m}^{3}(0.28 \%$ by cement weight). The Physical and mechanical properties of steel fibers are given in Table (2). 
Table 1. Physical and Mechanical Properties of Polypropylene fibers 300- $\mathrm{e}^{3}$. (as provided by manufacturer)

\begin{tabular}{|c|c|c|c|c|c|c|c|c|c|}
\hline $\begin{array}{c}\text { Fiber } \\
\text { Length }\end{array}$ & $\begin{array}{c}\text { Type/ } \\
\text { Shape }\end{array}$ & $\begin{array}{c}\text { Absorptio } \\
\mathrm{n}\end{array}$ & $\begin{array}{c}\text { Specific } \\
\text { Gravity }\end{array}$ & $\begin{array}{c}\text { Electrical } \\
\text { Conductivit } \\
\mathrm{y}\end{array}$ & $\begin{array}{c}\text { Acid \&Salt } \\
\text { Resistance }\end{array}$ & $\begin{array}{c}\text { Melt } \\
\text { Point }\end{array}$ & $\begin{array}{c}\text { Ignition } \\
\text { Point }\end{array}$ & $\begin{array}{c}\text { Thermal } \\
\text { Conductivity }\end{array}$ & $\begin{array}{c}\text { Alkali } \\
\text { Resist. }\end{array}$ \\
\hline $\begin{array}{c}\text { Averag } \\
\mathrm{e} 1.3 \mathrm{~cm}\end{array}$ & $\begin{array}{c}\text { Graded / } \\
\text { Fibrillated }\end{array}$ & Nil & 0.91 & Low & High & $\begin{array}{c}162^{\circ} \mathrm{C} \\
\left(324^{\circ} \mathrm{F}\right)\end{array}$ & $\begin{array}{c}593^{\circ} \mathrm{C} \\
\left(1100^{\circ} \mathrm{F}\right)\end{array}$ & Low & $\begin{array}{c}\text { Alkali } \\
\text { Proof }\end{array}$ \\
\hline
\end{tabular}

Table 2. Mechanical Properties of Steel fibers

\begin{tabular}{|c|c|c|c|c|c|}
\hline Relative density & Length $(\mathrm{cm})$. & $\begin{array}{c}\text { Diameter } \mu \mathrm{m} \\
0.00039 \mathrm{~cm} \\
(0.001 \mathrm{in} .)\end{array}$ & $\begin{array}{c}\text { Tensile strength } \\
\mathrm{MPa}\end{array}$ & $\begin{array}{c}\text { Modulus of } \\
\text { elasticity MPa }\end{array}$ & $\begin{array}{c}\text { Strain at } \\
\text { failure } \%\end{array}$ \\
\hline 7.8 & $2.32-5.43$ & $\begin{array}{c}39.3-393 \mathrm{~cm} \\
(100-1000 \mathrm{in} .)\end{array}$ & $500-2600$ & 210,000 & $0.5-3.5$ \\
\hline
\end{tabular}

\subsection{Concrete Mixes}

The concrete mixes were cast and cured in this study to investigate the effect of curing temperatures on the hardened properties of concrete mixes. The fibrous concrete compared to that of conventional concrete. Two types of fibers were used, polypropylene and steel fibers. The effects of curing temperatures $\left(25^{\circ} \mathrm{C}, 50^{\circ} \mathrm{C}\right.$ and $\left.75^{\circ} \mathrm{C}\right)$ were conducted.
Three concrete mixes F1 (non-reinforced concrete), mix F2 (polypropylene fiber reinforced concrete) and mix F3 (steel fiber reinforced concrete) were designed and casted by a ratio of coarse aggregate to fine aggregate $\mathrm{CA} / \mathrm{FA}=2 / 1$. These mixes were designed with a W/C ratio of 0.45 , fiber content of $0.98 \mathrm{~kg} / \mathrm{m}^{3}$ and cement content of $350 \mathrm{~kg} / \mathrm{m}^{3}$. Table (3) gives the concrete mixes proportions.

Table (3): The Proportions of the Concrete Mixes Used.

\begin{tabular}{|c|c|c|c|c|c|c|}
\hline Concrete Mixes & $\begin{array}{c}\text { Cement } \\
\left(\mathrm{kg} / \mathrm{m}^{3}\right)\end{array}$ & W/C \% & $\mathrm{CA} / \mathrm{FA}$ & $\begin{array}{c}\text { Steel Fibers } \\
\left(\mathrm{gm} / \mathrm{m}^{3}\right)\end{array}$ & $\begin{array}{c}\text { Polypropylene } \\
\text { Fibers }\left(\mathrm{gm} / \mathrm{m}^{3}\right)\end{array}$ & $\begin{array}{c}\text { Compressive } \\
\text { Strength } \\
\mathrm{F}_{\mathrm{cu} 28}(\mathrm{MPa})\end{array}$ \\
\hline $\mathrm{F} 1$ & 350 & 0.45 & $2 / 1$ & - & - & 32.0 \\
\hline $\mathrm{F} 2$ & 350 & 0.45 & $2 / 1$ & - & 980 & 32.3 \\
\hline F3 & 350 & 0.45 & $2 / 1$ & 980 & - & 32.2 \\
\hline
\end{tabular}

\subsection{Concrete Specimens}

The samples were mixed and cast in steel cubes $(100 \times 100 \times 100 \mathrm{~mm})$ cylinders $(100 \times 200 \mathrm{~mm})$ and beams $(100 \times 100 \times 500 \mathrm{~mm})$ after oiling its surface. After casting, the molds were compacted by using vibration table then; the specimens were covered by wet burlap in the laboratory temperature at $24^{\circ} \mathrm{C}$ and $68 \%$ relative humidity (R.H.). The specimens were demolded after 24 hours and the concrete mixes cured in water at different temperatures maintained till they were tested. The properties of the concrete mixes used are shown in Table (3).

The cubes, cylinders and prisms cured in water at different of temperatures of $25^{\circ} \mathrm{C}, 50^{\circ} \mathrm{C}$ and $75^{\circ} \mathrm{C}$ and tested at 3,7 and 28 days.

\subsection{Performed Tests}

The main mechanical properties of fibrous and plane concrete are obtained in terms of compressive strength, tensile strength and flexural strength. curing water $\left(25^{\circ} \mathrm{C}, 50^{\circ} \mathrm{C}\right.$ and $\left.75^{\circ} \mathrm{C}\right)$. Table (4) shows the test results at various ages.
Cubes of dimensions 100x100x100 mm was used to obtain compressive strength values. Cylinders of dimensions $100 \mathrm{~mm}$ diameter and $200 \mathrm{~mm}$ height were used to obtain indirect tensile strength values. Prisms of dimensions 100x100x500 mm was used to obtain flexural strength values. A compressive strength testing machine of $2000 \mathrm{kN}$ capacity was used to obtain compressive strength and indirect tensile strength. A flexure testing machine of 100 $\mathrm{kN}$ capacity was used to obtain flexural strength values.

\section{Test Results}

The properties of the fiber reinforced concrete (non- reinforced concrete as "F1", polypropylene fiber reinforced concrete as "F2" and steel fiber reinforced concrete as"F3") tested in this investigation included compressive strength, indirect tensile strength and flexural strength. The specimens were tested after curing the concrete at 3 , 7 and 28 days at different temperatures of 
Table (4): The Test Results at Various Ages.

\begin{tabular}{|c|c|c|c|c|c|c|c|c|c|c|}
\hline \multirow{2}{*}{ 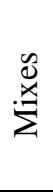 } & \multirow{2}{*}{$\begin{array}{c}\text { Curing } \\
\text { Temperatures }\end{array}$} & \multicolumn{3}{|c|}{$\begin{array}{l}\text { Compressive Strength } \\
(\mathrm{MPa})\end{array}$} & \multicolumn{3}{|c|}{$\begin{array}{l}\text { Indirect Tensile } \\
\text { Strength }(\mathrm{MPa})\end{array}$} & \multicolumn{3}{|c|}{$\begin{array}{c}\text { Flexural Strength } \\
(M P a)\end{array}$} \\
\hline & & $\begin{array}{c}3 \\
\text { Days }\end{array}$ & $\begin{array}{c}7 \\
\text { Days }\end{array}$ & $\begin{array}{c}28 \\
\text { Days }\end{array}$ & $\begin{array}{c}3 \\
\text { Days }\end{array}$ & $\begin{array}{c}7 \\
\text { Days }\end{array}$ & $\begin{array}{c}28 \\
\text { Days }\end{array}$ & $\begin{array}{c}3 \\
\text { Days }\end{array}$ & $\begin{array}{c}7 \\
\text { Days }\end{array}$ & $\begin{array}{c}28 \\
\text { Days }\end{array}$ \\
\hline \multirow{3}{*}{$\mathrm{F} 1$} & $25^{\circ} \mathrm{C}$ & 12 & 25.2 & 32 & 1.225 & 2.52 & 3.24 & 2.45 & 5.05 & 6.4 \\
\hline & $50^{\circ} \mathrm{C}$ & 13.4 & 28.5 & 35.9 & 1.25 & 2.57 & 3.3 & 2.48 & 5.1 & 6.5 \\
\hline & $75^{\circ} \mathrm{C}$ & 13.7 & 29.2 & 36.5 & 1.27 & 2.6 & 3.382 & 2.5 & 5.15 & 6.57 \\
\hline \multirow{3}{*}{$\mathrm{F} 2$} & $25^{\circ} \mathrm{C}$ & 12.1 & 25.45 & 32.3 & 1.32 & 2.75 & 3.57 & 2.7 & 5.7 & 7.4 \\
\hline & $50^{\circ} \mathrm{C}$ & 13.9 & 30 & 37.8 & 1.37 & 2.83 & 3.67 & 2.75 & 5.76 & 7.52 \\
\hline & $75^{\circ} \mathrm{C}$ & 14.4 & 31.3 & 39.1 & 1.35 & 2.82 & 3.62 & 2.73 & 5.72 & 7.67 \\
\hline \multirow{3}{*}{ F3 } & $25^{\circ} \mathrm{C}$ & 12.1 & 25.34 & 32.15 & 1.25 & 2.6 & 3.32 & 2.52 & 5.2 & 6.7 \\
\hline & $50{ }^{\circ} \mathrm{C}$ & 13.8 & 2.92 & 37 & 1.28 & 2.65 & 3.42 & 2.55 & 5.3 & 6.9 \\
\hline & $75^{\circ} \mathrm{C}$ & 14.2 & 30.6 & 38.3 & 1.3 & 2.68 & 3.5 & 2.58 & 5.4 & 7.05 \\
\hline
\end{tabular}

\subsection{Compressive Strength of Concrete}

Figures (1) to (6) showed the results of compressive strength tests for the different used concrete types (F1, F2 and F3) which cured in water different curing temperatures $\left(25^{\circ} \mathrm{C}, 50^{\circ} \mathrm{C}\right.$ and $75^{\circ} \mathrm{C}$ ) at 3,7 and 28 days.

Regarding to the test results of concrete specimens which cured in $25^{\circ} \mathrm{C}$, the compressive strength at 3 days age increased for the mixes F2 and $\mathrm{F} 3$ by about $0.9 \%$ compared to the control mix F1. For 7 days tests, the compressive strength increased for mixes $\mathrm{F} 2$ and F3 by about $1 \%$ compared to F1. Tests at 28 days showed that the mixes F2 and F3 decreased by about $1 \%$ compared to non-reinforced concrete mix F1. The using of fibers does not affect more the compressive strength at early ages of concrete see figure (1).

For the curing temperature at $50^{\circ} \mathrm{C}$, tests at 3 days showed that the compressive strength of the mixes F2 and F3 increased by about $16.4 \%$ and 3.8 $\%$ respectively compared to mix $\mathrm{F} 1$. Test results the compressive strength increased for mixes F2 and F3 by about $5.3 \%$ at 7 days and by about $5.3 \%$ and $3.1 \%$ at 28 days respectively compared to mix F1 as shown in Fig. (1).

The results of tested specimens which cured at $75^{\circ} \mathrm{C}$ are shown in Fig. (1). It showed that the compressive strength values of mixes F2 and F3 increased by $5.1 \%$ and $3.6 \%$ at the 3 days test while it increased by about $7.2 \%$ and $4.8 \%$ at 7 days test and by $7.1 \%$ and $4.9 \%$ at 28 days test respectively compared to control mix F1.

In other point of view for the relation between compressive strength and temperature for different concrete mixes F1, F2 and F3, the 3 days test showed that the mixes F1, F2 and F3 increased by about $0.8 \%$ at $25^{\circ} \mathrm{C}$ and $3.7 \%$ and $1.5 \%$ at $50^{\circ} \mathrm{C}$ and increased by about $5.1 \%$ and $3.6 \%$ at $75^{\circ} \mathrm{C}$ compared to plain concrete (control mix F1). At 7 days age the values of compressive strength increased for mixes $\mathrm{F} 2$ and $\mathrm{F} 3$ by $1 \%$ and $0.8 \%$ at $25^{\circ} \mathrm{C}$. But increasing curing temperature degrees increased the compressive strength for mix F2 by $5.3 \%$ and $7.2 \%$ at the temperature degrees of $50^{\circ} \mathrm{C}$ and $75^{\circ} \mathrm{C}$ respectively, while the compressive strength for mix F3 increased by $2.5 \%$ and $4.8 \%$ at the temperature degrees of $50^{\circ} \mathrm{C}$ and $75^{\circ} \mathrm{C}$ respectively compared to mix F1. In 28 days test the values of compressive strength increased for mix F2 by $5.3 \%$ and $7.1 \%$ at the temperature degrees of $50^{\circ} \mathrm{C}$ and $75^{\circ} \mathrm{C}$ respectively, for mix $\mathrm{F} 3$ the compressive strength decreased by 3.1 and $4.9 \%$ at the temperature degrees of $50^{\circ} \mathrm{C}$ and $75^{\circ} \mathrm{C}$, respectively, as shown in Figures (2 to 4).

The use of fiber does not affect the compressive strength. While using polypropylene fibers in concrete mixes improved the compressive strength of higher than the improving with using steel fibers because the percentage of steel fibers was very low compared to polypropylene fibers. 


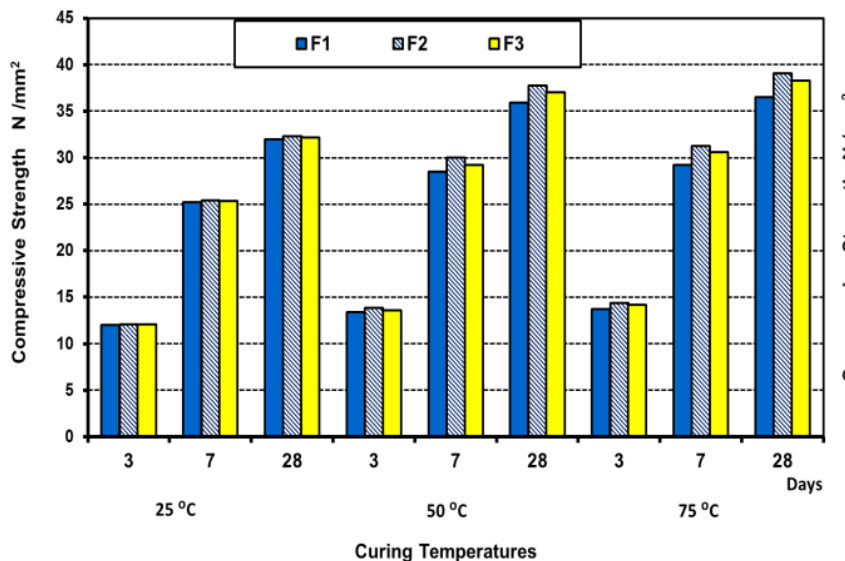

Figure (1): Compressive Strength for Different Concrete Types at Different Curing Temperatures

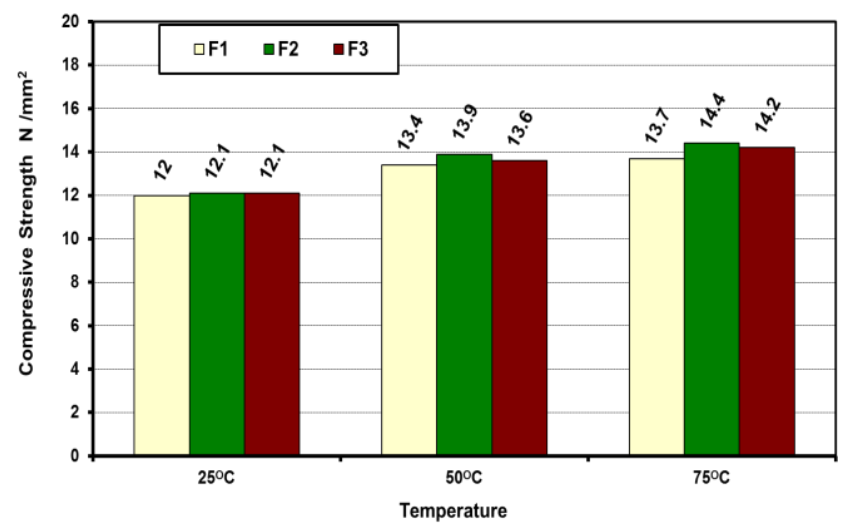

Figure (2): Compressive Strength for Different Curing Temperatures at 3 Days

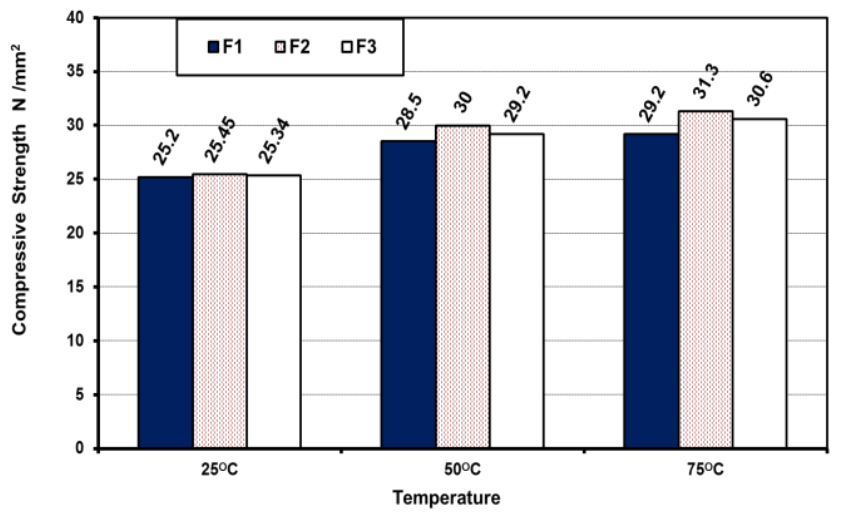

Figure (3): Compressive Strength for Different Curing Temperatures at 7 Days

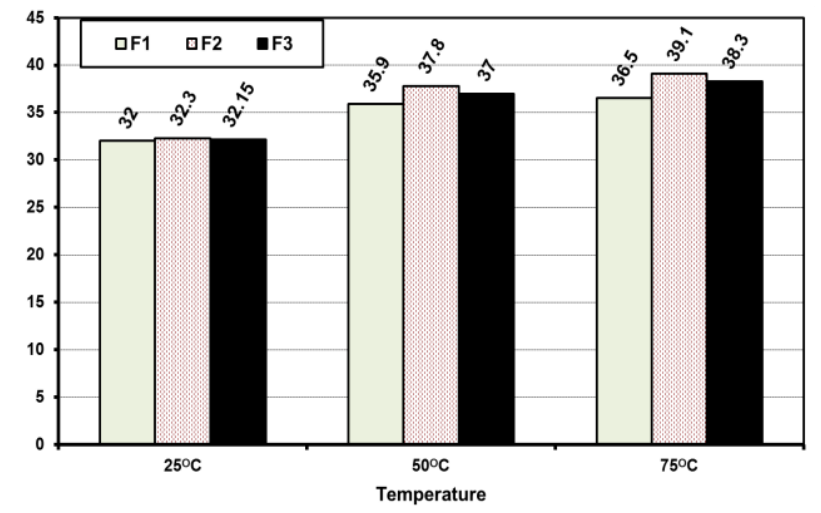

Figure (4): Compressive Strength for Different Curing Temperatures at 28 Days

\subsection{Tensile Strength of Concrete}

Results of the indirect tensile strength tests of concrete specimens for mixes $\mathrm{F} 1, \mathrm{~F} 2$ and $\mathrm{F} 3$ which cured in water of temperatures $25^{\circ} \mathrm{C}, 50^{\circ} \mathrm{C}$ and $75^{\circ} \mathrm{C}$ at 3,7 and 28 days are shown in Figures ( 5 to $8)$. For the tested concrete specimens which cured in $25^{\circ} \mathrm{C}$, the values of indirect tensile strength increased by about $7.8 \%, 9 \%$ and $10.2 \%, 2 \%$, $3.1 \%, 2.5 \%$ for the mixes $\mathrm{F} 2$ and $\mathrm{F} 3$ respectively at 3,7 and 28 days respectively as shown in figure (5) compared to the plain concrete mix F1.

For the temperature of $50^{\circ} \mathrm{C}$, tests at 3 days showed that the indirect tensile strength of the samples mixes F2 and F3 increased by about 9.6\% and $2.4 \%$ respectively compared to mix $\mathrm{F} 1$. The tensile strength of concrete mix F2 increased by about $5.3 \%$ at 7 and 28 days tests while increased by $3.1 \%$ and $3.6 \%$ at 7 and 28 days for mix F3 respectively compared to mix $\mathrm{F} 1$. At the temperature of $75^{\circ} \mathrm{C}, 3$ days test showed that the values of tensile strength of samples cast with mixes F2 and F3 increased by $6.3 \%$ and $2.4 \%$ respectively compared to mix F1. Those values increased by about $8.5 \%$ and $7 \%$ for mix F2 at 7 and 28 days tests while increased the tensile stress by $3.1 \%$ and $3.5 \%$ at 7 and 28 days for mix F3 respectively compared to mix $\mathrm{F} 1$ as shown in Figure (5).

The performance of the samples cast with mixes F1, F2 and F3 are nearly the same in the behavior but at various curing temperatures of $25^{\circ} \mathrm{C}, 50^{\circ} \mathrm{C}$ and $75^{\circ} \mathrm{C}$ as shown in Fig. (5).

Test results at 3 days age showed that the values of indirect tensile strength for concrete mixes F2 and $\mathrm{F} 3$ increased by $7.8 \%$ and $2 \%$ at $25^{\circ} \mathrm{C}$ while increased by about $9.6 \%$ and $2.4 \%$ at $50^{\circ} \mathrm{C}$ compared to $\mathrm{F} 1$. The indirect tensile values also increased by about $6.3 \%$ and $2.4 \%$ at $75^{\circ} \mathrm{C}$ compared to F1. 
The 7 days test showed that the values of indirect tensile strength increased at $25^{\circ} \mathrm{C}$ for the samples mixes $\mathrm{F} 2$ and $\mathrm{F} 3$ by $7.8 \%$ and $2 \%$ respectively. The values of indirect tensile strength increased for mix $\mathrm{F} 2$ at curing temperatures of $50^{\circ} \mathrm{C}$ and $75^{\circ} \mathrm{C}$ by about $9.6 \%$ and $6.3 \%$ respectively. While the increasing of indirect tensile strength for the mix F3 by $3.1 \%$ at the same two pervious temperatures. At 28 days test, the values of indirect tensile strength increased by about $6.3 \%$ and $2.4 \%$ at $25^{\circ} \mathrm{C}$ for the fiber reinforced concrete mixes $\mathrm{F} 2$ and $\mathrm{F} 3$ respectively. For the curing temperatures of $50^{\circ} \mathrm{C}$ and $75^{\circ} \mathrm{C}$, the values of indirect tensile strength increased for the polypropylene fiber reinforced concrete mix F2 by about $11.2 \%$ and $7 \%$ respectively, while increased for the steel fiber reinforced concrete mix $\mathrm{F} 3$ by $3.6 \%$ and $3.5 \%$ respectively at the same two pervious temperatures as shown in Figures (6-8).

The use of fibers improves the indirect tensile strength. Using polypropylene fibers in concrete mixes improves the indirect tensile strength compared to steel fibers because the amount of steel fibers was very low compared to polypropylene fibers (due to using the same weight for both).

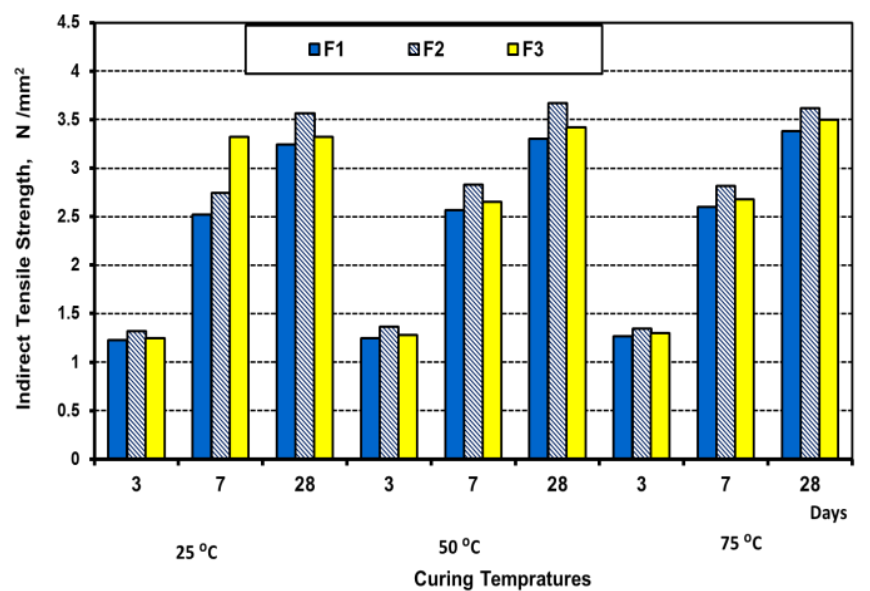

Figure (5): Tensile Strength for Different Concrete Types at Different Curing Temperatures.

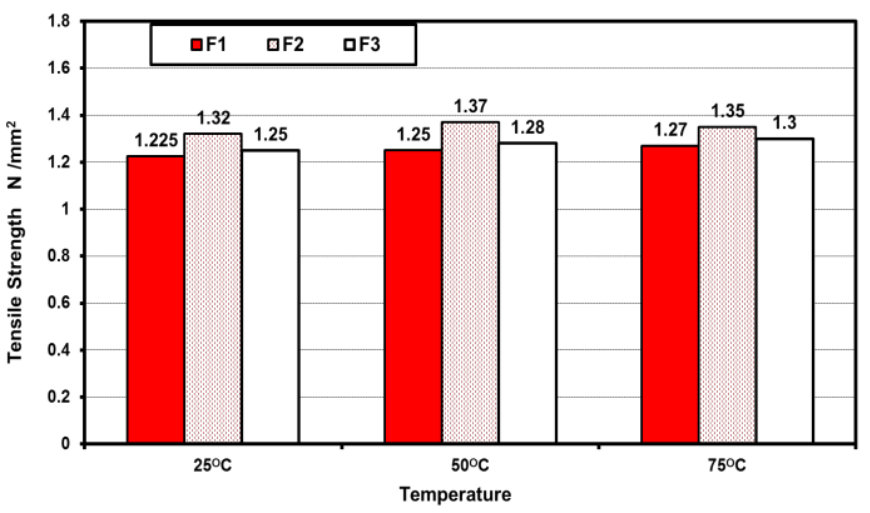

Figure (6): Tensile Strength at Different Curing Temperatures at 3 Days Age.

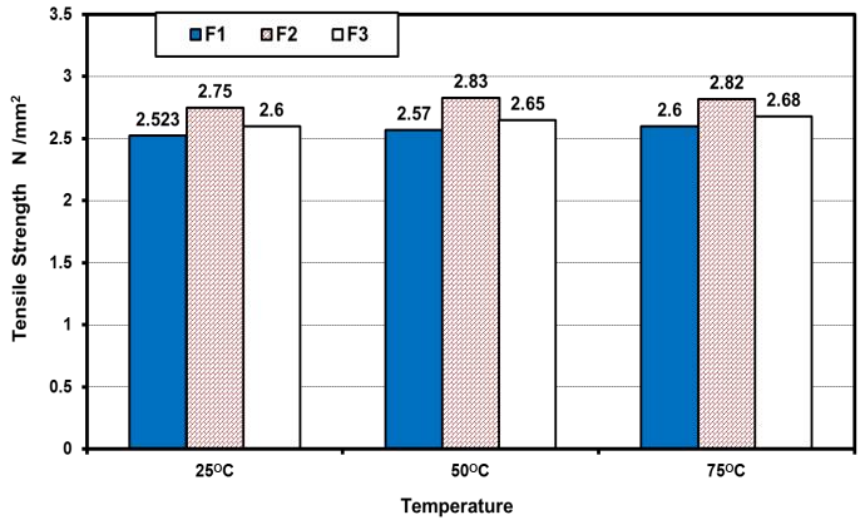

Figure (7): Tensile Strength at Different Curing Temperatures at 7 Days Age.

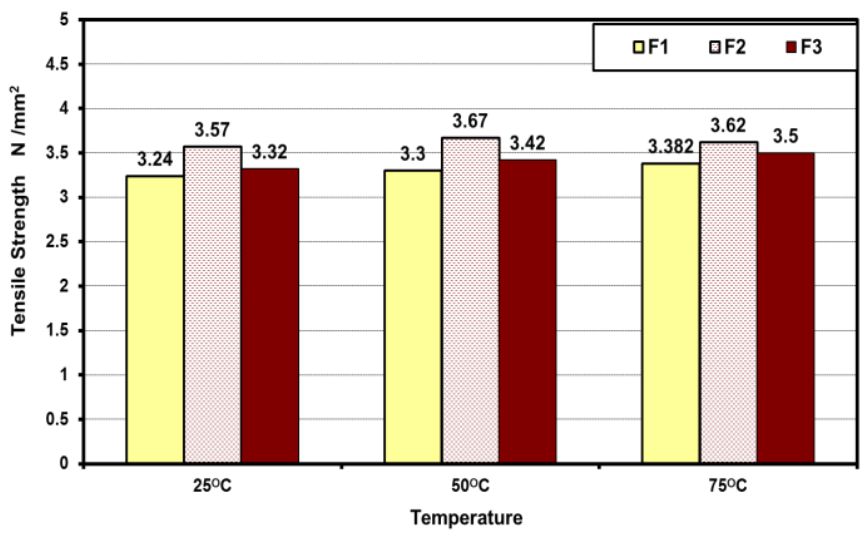

Figure (8): Tensile Strength at Different Curing Temperatures at 28 Days Age.

\subsection{Flexural Strength of concrete}

Results of the flexural strength tests of concrete specimens cast with mixes F1, F2 and F3 which cured in curing water at temperatures $25^{\circ} \mathrm{C}, 50^{\circ} \mathrm{C}$ and $75^{\circ} \mathrm{C}$ at 3,7 and 28 days are shown in figures (9 to 12). For the tested concrete specimens which 
.

cured in $25^{\circ} \mathrm{C}$, the values of flexural strength increased for the mixes F2 and F3 by about $10.2 \%$, $2.9 \%$ and $12.9 \%, 3 \%$ and $15.6 \%, 4.7 \%$ at 3,7 and 28 days respectively as shown in Figure (9) compared to the plain concrete mix F1.

For the temperature of $50^{\circ} \mathrm{C}$, tests at 3 days showed that the flexural strength of the samples cast with mixes F2 and F3 increased by about $3.7 \%$ and $1.5 \%$ respectively compared to mix $\mathrm{F} 1$. The flexural strength of concrete mix F2 increased by about $5.3 \%$ at 7 and 28 days tests while increased by 2.5 and $3.1 \%$ at 7 and 28 days for mix F3 respectively compared to mix $\mathrm{F} 1$ at the same curing temperature. At 3 days ages and $75^{\circ} \mathrm{C}$ curing temperature, the values of flexural strength of samples cast with mixes $\mathrm{F} 2$ and $\mathrm{F} 3$ increased by $5.1 \%$ and $3.6 \%$ respectively compared to mix F1.

The values of flexural strength increased by about $7.2 \%$ and $7.1 \%$ for mix $\mathrm{F} 2$ at 7 and 28 days ages, while it increased by $4.8 \%$ and $4.9 \%$ at 7 and 28 days for mix F3 respectively compared to mix F1 as shown in Figure (9).

Test results at 3 days age showed that the values of flexural strength for concrete mixes F2 and F3 increased by $10.2 \%$ and $10.9 \%$ at $25^{\circ} \mathrm{C}$ while increased by about $9.2 \%$ and $2.9 \%$ at $50^{\circ} \mathrm{C}$ compared to mix F1. The flexural strength values also increased by about $2.8 \%$ and $3.2 \%$ at $75^{\circ} \mathrm{C}$ compared to mix F1. At 7 days test showed that the values of flexural strength increased at $25^{\circ} \mathrm{C}$ for the samples cast with mixes $\mathrm{F} 2$ and F3 by $12.9 \%$ and $3 \%$ respectively. The values decreased for mix F2 at curing temperatures of $50^{\circ} \mathrm{C}$ and $75^{\circ} \mathrm{C}$ by about $12.9 \%$ and $11.1 \%$ respectively, while increased for the mix $\mathrm{F} 3$ by $3.9 \%$ and $4.9 \%$ respectively at the same two pervious temperatures.

At 28 days age, the values of flexural strength increased by about $15.6 \%$ and $4.7 \%$ at $25^{\circ} \mathrm{C}$ for the fiber reinforced concrete mixes $\mathrm{F} 2$ and $\mathrm{F} 3$ respectively. For $50^{\circ} \mathrm{C}$ and $75^{\circ} \mathrm{C}$ curing temperatures, the values of flexural strength decreased for the polypropylene fiber reinforced concrete mix F2 at by about $15.7 \%$, while increased for the steel fiber reinforced concrete mix F3 by $6.2 \%$ and $3.7 \%$ respectively at the same two pervious temperatures, as shown in Figures (10 to 12).

Using of fibers improved the flexural strength values compared to plain concrete.

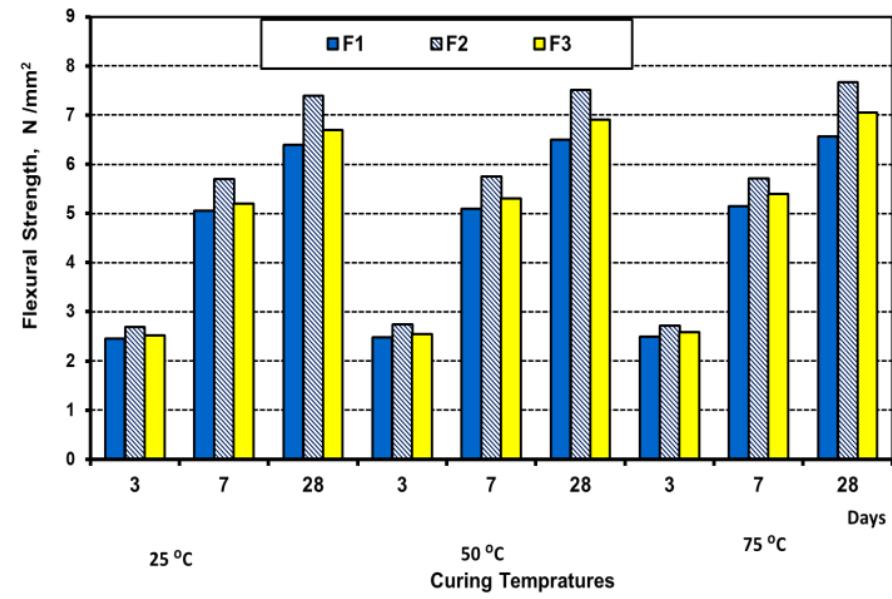

Figure (9): Flexural Strength for Different Concrete Types at Different Curing Temperatures

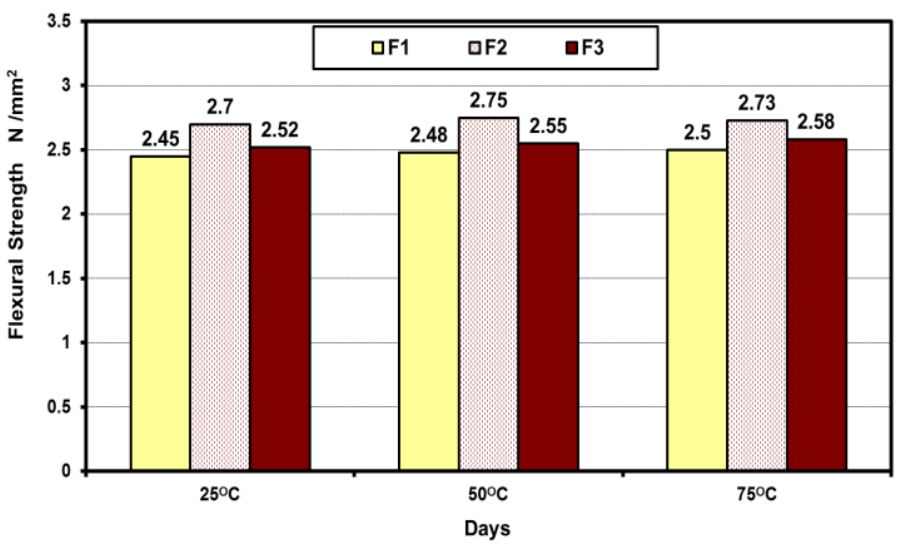

Figure (10): Flexural Strength at Different Curing Temperatures for 3 Days Ages

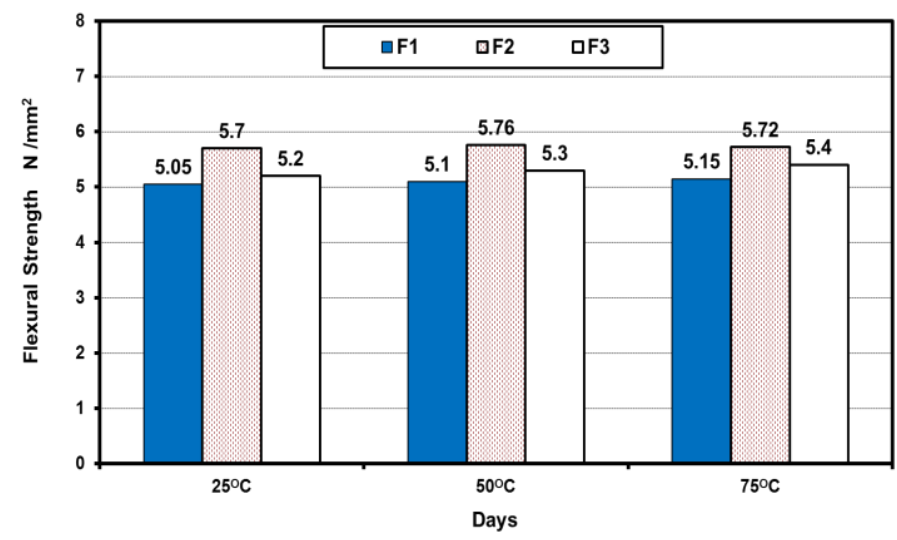

Figure (11): Flexural Strength at Different Curing Temperatures for 7 Days Ages 


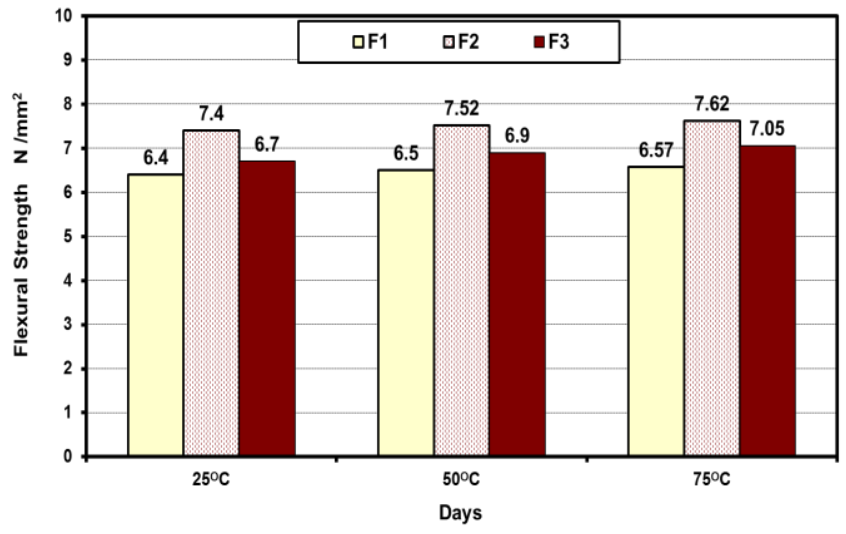

Figure (12): Flexural Strength at Different Curing Temperatures for 28 Days Ages

\section{Conclusions}

Based on the experimental studied in this research the following conclusions can be obtained:

1. Increasing the temperature of curing water (up to about $50^{\circ} \mathrm{C}$ ) increases the compressive, tensile and flexural strength values at different ages.

2. The polypropylene fibers reinforced concrete F2 scored higher strength values compared to steel fibers reinforced concrete F3.

3. At 3 days tests, using fibre reinforced concrete increased compressive strength at different temperatures. The higher values scored for the sample F2 then F3 followed by F1 at different degrees of temperatures.

4. At 7 and 28 days tests, the higher the compressive strength values scored for F1 followed by the polypropylene fibers reinforced concrete $\mathrm{F} 2$ then steel fibers reinforced concrete $\mathrm{F} 3$ at $25^{\circ} \mathrm{C}, 50$ and $75^{\circ} \mathrm{C}$.

5. Using fibres as concrete reinforcement increasing the values of indirect tensile strength at 3 days test but the effect decreased at 7, 28 days tests.

6. The value of the indirect tensile strength was improved by increase the curing temperatures and using polypropylene fibers and steel fibres.

7. The best curing temperature was $50^{\circ} \mathrm{C}$ and 75 ${ }^{\circ} \mathrm{C}$ for polypropylene fibers and steel fibers in properties of hardened concrete (compressive, tensile and flexural strength) respectively.

\section{References}

[1] Jerzy Z. Zemajtis, "Curing Concrete in Construction", Portland cement Association, (Valid on line at: http://www.cement.org/tech/cct_curing.asp accessed at: 12 October 2013)

[2] American Concrete Institute, ACI 308 (2011)\& ACI 308.1-11, "Standard Practice for Curing Concrete", Farmington Hills, Detroit, USA.

[3] American Concrete Institute (ACI) (2010), ACI 306R-10, "Standard Specification for Cold Weather Concreting", Farmington Hills, Detroit, USA.

[4] American Concrete Institute (ACI) (2010), ACI 305R-10, "Specification for Hot Weather Concreting", Farmington Hills, Detroit, USA.

[5] Erdem T., 2003, "Setting time: an important criterion to determine the length of the delay period before steam curing of concrete", Cement and Concrete Research, Vol. 33, pp.741-750.

[6] Paya J., Monzo J., Perismora E., Borrachero M., Tercero R., Pinillos C., 1995, "Early-strength Development of Portland Cement Mortars Containing air Classified Fly Ashes", Cement and Concrete Research, Vol. 25, p. 449.

[7] Burg, R. G., 1996, "The influence of casting and curing temperature on the properties of fresh and hardened concrete", Res. Devel. Bull. RD113T, Oregon: Portland cements Association, Portland.

[8] Lker Bekir Topc U., 2005, "Fine Aggregate and Curing Temperature Effect on Concrete Maturity" Cement and Concrete Research Vol.35, pp.758-762.

[9] National Ready Mixed Concrete Association NRMCA, 2000, "Effect of Curing Condition on Compressive Strength of Concrete Test Specimens", NRMCA Publication No.53, Silver Spring,

[10] Bashandy A. A., Soliman N. M., 2013, "Influence of Fine to Coarse Aggregate Ratio and Curing Temperatures on the Behavior of Concrete", Engineering Research Journal, Faculty of Engineering - Mataria, Helwan University, Egypt, June 2013, Vol.138, pp. c30-c42.

[11] Turkel S., Alabas V., 2005, "The Effect of Excessive Steam Curing on Portland Composite Cement Concrete", Cement and Concrete Research, Vol. 35, p. 405.

[12] E.S.S. No. 1109, 2008, "Aggregate", Egyptian Standard Specification, Ministry of Industry, Cairo, Egypt.

[13] ASTM C33-03, "Standard Specification for Concrete Aggregates", USA.

[14] E.S.S. No. 4756-1, 2009, "Portland Cement, Ordinary and Rapid Hardening", Egyptian Standard Specifications, Ministry of Industry, Cairo, Egypt. 